\title{
Evaluating the Performance and Profitability of Bread Wheat (Triticum Aestivum L) Varieties under Farmers Training Center at Hitosa District,Oromia Regional State, Ethiopia
}

\author{
Sintayehu Abebe ${ }^{1}$ Hashim Gelete ${ }^{2}$ \\ Ethiopian Institute Of Agricultural Research, Kulumsa Agricultural Research Center,Assela, Ethiopia \\ P. O.Box 489
}

\begin{abstract}
The aim of this study was to evaluate the performance and profitability of improved bread wheat varieties at Seruanketo kebele of Hitosa district,Arsi Zone. Along with their management practices under farmers' Training center (FTC) field to enhance farmers' knowledge and skill on bread wheat production performance and it profitability. The varities used to demonistrate were Four improved bread wheat varieties namely DAKA, Wane(check),Lemu \& Honkolo. According to the results, an average yield of $52 \mathrm{qt} / \mathrm{ha}, 40 \mathrm{qt} / \mathrm{ha} 36 \mathrm{qt} / \mathrm{ha}$ and 30qt/was harvested from DAKA,Honkolo,Wane \& Lemu varieties respectively. DAKA variety had a $44.4 \%$ yield advantage over the standard check (Wane) and Honkolo had a $11.1 \%$ yield advantage over the standard check and the variety Lemu had a negative $-16.6 \% \%$ yield loss or below the standard check and the Autors conclude that both DAKA\& Honkolo varities are the first and second option for the farmers whereas the variety Lemu is not recommended due to low productivity in the study area and others areas having similar agro ecologies.Economic analysis showed that DAKA had the highest net benefit $(110,647 \mathrm{bir} / \mathrm{ha})$ followed by Honkolo(77046.75 bir/ha),Wane(66171 Bir/ha) and variety Lemu had a $(50,671 \mathrm{Bir} / \mathrm{ha})$ had the lowest net benefit. Based on the rules of decision making and the yield advantages on the bread wheat varieties the tested varieties met the requirements for recommendation, Therefore, DAKA and Honkolo varieties in addition to Wane (The standard check) were recommended for Seruanketo kebele and other areas with similar agroecological conditions in the South eastern districts.
\end{abstract}

Keywords: Bread wheat, Pre-extension, Demonstration, Farmer Training Center (FTC)

DOI: $10.7176 / \mathrm{DCS} / 10-12-04$

Publication date: December $31^{\text {st }} 2020$

\section{Introduction}

Wheat (Triticumaestivum L.) is one of the most important staple food crops in the world Dereje Dobocha (2019). It is grown in a wider range of altitude between 1500 to 3000 meter above sea level m.a.s.l and best suitable agro-ecological zones,ranges between 1900 and 2700 m.a.s.l . Wheat is known to be a major source of energy and protein Tesfaye Gemechu (2018).It is the fourth largest cereal crop produced by about 5 million smallholder farmers, which is more than $1 / 3$ of all small holder farmers in EthiopiaWuletaw Tadesse (2018).

Among the crops bread wheat (Triticum aestivum L ) makes a significant contributions for both agricultural development and food security(Asrat 2020). At the global level with a production of 750 million tons (MT) on about 220 million hectares (Mha) in 2017 and Africa produces more than 25 million tons of wheat on 10 Mha.Wuletaw Tadesse (2018)

The major wheat producing countries in Sub Saharan African (SAA) are Ethiopia, South Africa, Sudan, Kenya, Tanzania, Nigeria, Zimbabwe and Zambia in descending order. Ethiopia accounts for the largest production area (1.7 Mha) followed by South Africa (0.5 Mha)Wuletaw Tadesse (2018).After South Africa, Ethiopia is the second largest wheat producer in sub-Saharan AfricaSolomon Yokamo (2018). Asmamaw Demil (2020). The major wheat producing areas in Ethiopia are located in Arsi, Bale, Shewa, Ilubabor,Western Hareghe, Sidamo, Tigray, (Bekele Gemechu 2018). Although the country is the major Samuel Gebreselassie (2017)producer in sub Saharan Africa it is still reliant on foreign wheat import to satisfy its demands

The national average of wheat yield of Ethiopia is around 2.9 t/ha (CSA 2019/20), which is far below from potential yields of the crops from research field which is over $5 \mathrm{t} / \mathrm{ha}$. To minimize this problem and enhance production and productivity efforts were made by the research and extension system of the country by releasing and demonstrating improved varieties along with their management practices. Additionally, the yield gap of 2 t/ha indicates the potential for increasing productivity of wheat production through utilization of agricultural inputs, including quality seed of the improved varities.

To fill agricultural technology gap, now days, the Ethiopian Institute of Agricultural Research (EIAR) remains the primary agricultural research agency took the responsibility for generation of agricultural technology (Samuel Gebreselassie (2017).

Generating and adapting high yielding, disease tolerant and relatively stable varieties that can meet increasing Bread Wheat seed \& contribute to improve production and productivity \& finally pave the way for 
import substitutions are very important.

Generally promoting the newly released varieties with their full recommendation package is to enable farmers' to select the best fit \& profitable varieties of their interest. To achieve this, Kulumsa Agricultural Research Center (KARC) has been promoting high yielder varieties of Bread Wheat under farmers Training Center (FTC) demonstration field by pre-extension demonstration (PED) approach to potential area of Hitosa District of Arsi zone, in 2019/20 cropping season with the objectives to evaluate the performance and profitability of bread wheat varieties under Farmers Training Center (FTC).

\section{MATERIAL AND METHODS}

Description of the Study Areas

The study was conducted in Hitosa district of Arsi zone. Arsi zone is one the Administrative zones of Oromia regional state, Ethiopia. Assela town is serving as the capital town of the zone. There are 25 districts within the zone among which Hitosa district is the study district where this demonstration activity took place .Hitosa district is located at $150 \mathrm{~km}$ from the capital city of Ethiopia, Addis Ababa and $25 \mathrm{~km}$ from zonal capital Assela.(Wikipedia 2020). The altitude of this woreda ranges from 1500 to 4170 meters above sea level(Wikipedia 2020).

Hitosa has 23 Kebele's among which one kebele namely Seruanketo was used for this study. The major crops produced are wheat, barley, teff and maize and Onions and potatoes are important cash crops(HOANR 2019).It has an Latitude (DMS)of $8^{\circ} 04^{\prime} 60.00^{\prime \prime} \mathrm{N}$ and Longitude (DMS) 39 $14^{\circ} 60.00^{\prime \prime}$ E.(Wikipedia 2020).

\section{Demonstration field Site Selection}

The demonstration was conducted in selected Kebele of Hitosa district of Arsi zone.one kebele from the distrct (seruanketo) was selected based on its wheat production potential. From the kebele in collaboration with agricultural experts one farmers training centers (FTC) was selected based on the availability of enough land and furnished (fenced) FTC for the trial establishment.

Then land preparation was implemented with using machine and four varieties were selected for trial based on recent releasing. Then the varieties planted on $10 \mathrm{~m} * 10 \mathrm{~m}$ for each variety.

Packaged production technologies (seed rate, spacing, fertilizer management and weed management) recommended for the bread wheat production was used to establish the trials.

Four improved varieties of Seeds were sown at the recommended rate of $150 \mathrm{~kg}$ ha-1 in rows. Urea $(46 \% \mathrm{~N})$ was used as a source of nitrogen fertilizer. $2 / 3$ of $\mathrm{N}$ fertilizer was applied within the rows as basal application at planting. The remaining $1 / 3$ dose of nitrogen fertilizer was top-dressed at tillering stage. Beside this NPS fertilizer was applied at the rate of $121 \mathrm{~kg}$ ha-1. Plots were kept free of weeds. Field visits at different stage of the crop were arranged and one field day was organized at seruanketo kabala to evaluate the performance of the verities and to collect farmer's feedback and finally actual yield was harvested and recorded.

\section{Planting Material}

Four adaptable bread wheat varieties (DAKA,Wane,Lemu \&Honkolo) were used. Planting material (Seed) were prepared in advance from Kulumsa Agricultural Research center (May 2019).

Table 2 Characteristics of bread wheat varieties used for the activity

\begin{tabular}{|l|l|l|l|l|}
\hline Characteristics & $\begin{array}{l}\text { DAKA(ETBW } \\
7638)\end{array}$ & Wane(ETBW 6130) & $\begin{array}{l}\text { Lemu (ETBW } \\
6861)\end{array}$ & $\begin{array}{l}\text { HONQOLO (ETBW } \\
5879)\end{array}$ \\
\hline Adaptation area & Mid to lowland & Mid to high land & High land & High land \\
\hline Days to maturity & 75 & 125 & 140 & 115 \\
\hline Altitude (m.a.s.l) & $1600-2200$ & $2100-2700$ & $>2200$ & $2200-2850$ \\
\hline Rainfall (mm) & $500-800$ & $700-1000$ & $800-1100$ & $750-1200$ \\
\hline Year of release & 2018 & 2016 & 2016 & 2014 \\
\hline $\begin{array}{l}\text { Yield potential (t/ha): } \\
\text { at Research field }\end{array}$ & 5.6 & $5-6$ & $5.5-6.5$ & $3.5-6.3$ \\
\hline
\end{tabular}

\section{Technology Gap and Technology Index}

For this study technology gap and index were also calculated. The technology gap shows the gap in the demonstration yield over potential yield.

As mentioned in (Tesfaye Gemechu 2018), The observed technology gap is attributed to mismatch in agro ecologies factors and other variability of weather conditions. Its contribution is to narrow down the gap between the yields of different varieties, and to provide location specific recommendations.

Moreover, the yield gaps can be further categorized into technology index which is used to show the feasibility of the variety at the Farmers Training Center (FTC).

The lower the value of technology indexes the more the feasibility of the varieties. To this end, the 
technology gap and technology index of demonstrated Varieties in this study (DAKA. Honkolo ,Wane \& Lemu ) were calculated using the following formulas adopted from (Maitra 2000) .

Technology gap $=$ Potential yield $\mathrm{qt} / \mathrm{ha}-$ demonstration yield

Technology index $\%=\underline{\text { Potential yield }- \text { demonstration yield } \mathrm{X} 100}$

Potential yield

\section{Data Collected}

To compare the productivity of varieties Actual grain yield was collected in addition to this Costs and income gained from the trial was collected and manipulated to the farmer's context again to understand the farmer's perception towards varieties Likert -like scale was applied to analyses the collected data.

\section{Data Analysis}

The collected actual grain yield and financial data was analyzed using SPSS ver 20 and present in tables. The technology gap and technology index were calculated using the formulas as given by (Maitra 2000), as shown above.

\section{RESULT AND DISCUSSION}

Yield Performance of the Varieties Demonstrated at FTC demonstration field (at Seruanketo kabale).

As indicated in table 1 shows the analysis result on actual yield performance of the varieties demonstrated in the district. According to the result a yield of 52qt ha, 40qt/ha, 36qt/ha and 30qt/ha were harvested from DAKA. Honkolo, Wane \& Lemu varieties respectively.

Table 3 Technology gap and index of DAK,Wane,Lemu \& Honkolo bread wheat varieties at Hitosa district

\begin{tabular}{|l|l|l|l|l|}
\hline \multirow{2}{*}{ Parameters } & Bread wheat varieties & \multicolumn{4}{l|}{} \\
\cline { 2 - 5 } & DAKA & Honkolo & Wane & Lemu \\
\hline Yield potential (qt/ha): at Research field & 56 & $35-63$ & $\mathbf{5 0 - 6 0}$ & $\mathbf{5 5 - 6 5}$ \\
\hline Yield harvested (qt/ha) at study area & $\mathbf{5 2}$ & $\mathbf{4 0}$ & $\mathbf{3 6}$ & $\mathbf{3 0}$ \\
\hline Yield gap (qt/ha) & $\mathbf{4}$ & $\mathbf{2 3}$ & $\mathbf{2 4}$ & $\mathbf{3 5}$ \\
\hline Technology index (\%) & $\mathbf{7 . 1}$ & $\mathbf{3 6 . 5}$ & $\mathbf{4 0}$ & $\mathbf{5 3 . 8}$ \\
\hline
\end{tabular}

As it can calculated from the above table 1, the average technology index percentage is $7.1 \%$ for DAKA variety, $36.5 \%$ for Honkolo variety , $40 \%$ for Wane variety, $53.8 \%$ for Lemu variety .the lower the percentage of technology index the higher will be the option for the production.

Again the yield gap analysis indicate that there is a wide different average among all varieties in their average yield gap and yield performance between this demonstration and the potential of the varieties, having 4 qt/ha, 23qt/ha ,24qt/ha, 35qt/ha and 40qt/ha for DAKA, Honkolo Wane \& Lemu respectively. This indicates that the varieties DAKA, Honkolo, Wane \& Lemu are the first and second option of varieties for farmers respectively and all are feasible if produced in the study areas \& other areas having similar agro ecologies.

Yield advantage of the varieties Under Farmers training center (FTC ) from demonstration plot at the study area in 2019 cropping season

Yield advantage $\%=\frac{\text { Yield of new variety (qt/ha) }- \text { Yield of standard check }}{\text { Yield of standard check }(\mathrm{qt} / \mathrm{ha})}$ X 100

Yield advantage $\%$ for DAKA $\left.=\frac{52 \mathrm{qt} / \mathrm{ha}-\mathbf{3 6}}{36 \mathrm{qt} / \mathrm{ha}} \mathrm{t} / \mathrm{ha}\right) \mathrm{X} \mathbf{1 0 0}=\mathbf{4 4 . 4 \%}$

Yield advantage $\%$ for Honkolo $=\underline{40 \text { qt } / \text { ha }-36}$ qt/ha)X 100=11.1\% 36qt/ha

Yield advantage $\%$ for Lemu $=\underline{\mathbf{3 0} \text { qt } / \mathbf{h a}-\mathbf{3 6}} \mathbf{q t} / \mathbf{h a}) \mathbf{X} 100=\mathbf{- 1 6 . 6} \%$ 36qt/ha

The overall harvested mean yield of DAKA, Honkolo \& Lemu was 52qt/ha, $40 \mathrm{qt} / \mathrm{ha}$ and $30 \mathrm{qt} / \mathrm{ha}$ the, respectively. The yield advantage of DAKA variety over the standard check (wane) variety was $44.4 \%$,again the yield advantage of the variety Honkolo over the standard check (wane) was $11.1 \%$ and the yield advantage of the variety Lemu over the standared check was $-16.6 \%$ which was below the check.

\section{FINANCIAL ANALYSIS}

In terms of profitability the financial analysis result show that an average return of 110,647 Birr, 77046.75 Birr, 66171 Birr, 50671 Birr per hectare can be gained from DAKA,Honkolo,Wane \& Lemu varieties respectively in 2019 cropping season in the study areas. 
Table 4 cost benefit analysis

\begin{tabular}{|c|c|c|c|c|}
\hline \multirow[t]{2}{*}{ Parameters } & \multicolumn{4}{|l|}{ varieties } \\
\hline & DAKA & Honkolo & Wane & Lemu \\
\hline Yield qt/ha (Y) & 52 & 40 & 36 & 30 \\
\hline Price $(P)$ per quintal & 3100 & 3100 & 3050 & 3050 \\
\hline Total Revenue $(T R)=T R=Y x P$ & 161,200 & 124000 & 109800 & 91500 \\
\hline \multicolumn{5}{|l|}{ Variable costs } \\
\hline Seed cost & 2760 & 2760 & 2760 & 2760 \\
\hline Fertilizer cost & 3200 & 2600 & 1600 & 2400 \\
\hline Chemicals & 11193.3 & 11193.25 & 9969 & 9969 \\
\hline labor cost & 2500 & 2100 & 2200 & 1900 \\
\hline Combiner harvesting & 2600 & 2000 & 1800 & 1500 \\
\hline Cost of transport, sacks & 300 & 300 & 300 & 300 \\
\hline Total variable costs (TVC) & 22553.3 & 20953.3 & 18629 & 18829 \\
\hline \multicolumn{5}{|l|}{ Fixed costs } \\
\hline Cost of land & 28000 & 26000 & 25000 & 22000 \\
\hline Total fixed costs (TFC) & 28000 & 26000 & 25000 & 22000 \\
\hline Total Cost $(\mathrm{TC})=\mathrm{TVC}+\mathrm{TFC}$ & 50553.3 & 46953.25 & 43629 & 40829 \\
\hline Gross Margin (GM) = TR TVC & 138,647 & 103046.75 & 91171 & 72671 \\
\hline Profit in ETH birr= GM-TFC & 110,647 & 77046.75 & 66171 & 50671 \\
\hline
\end{tabular}

\section{CONCLUSION AND RECOMMENDATION}

The results indicated that all varieties demonstrated gave promising yield having $7.1 \%, 36.5 \%, 40 \%$ and 53.8 yield advantage of the varieties DAKA, Honkolo, Wane \& Lemu varieties respectively.

Furthermore, all varieties were evaluated in their economic return. The results indicate that all

Varieties are profitable the farmers can earn

$>110,647$ Ethiopian birr from producing DAKA variety,

$>77046.75$ Ethiopian birr from producing Honkolo variety,

$>$ 66,171 Ethiopian birr from producing Wane variety and

$>$ 50,671 Ethiopian birr from producing Lemu variety

Therfore, based on this result the author recommend producing DAKA, \& Honkolo as the first and the second options for production of bread wheat varieties.

Eventhough, producing the variety Lemu can earn 50,671 Ethiopian birr but the yield advantage over the standard check (wane) was negative, Therfore, the authors recommended not to produce the variety Lemu at the study area and other areas that have similar agro ecologies.

In addition the technology index and yield gap analysis also shows as the varieties are feasible for farmers in the study area if scaled up in large size land. The varieties DAKA, Honkolo\& Wane As the first, second and third options in the study areas and its surrounding having similar agro ecologies.

Therefore, all varieties can be used for further scaling up activities in Hitosa district and areas which have similar agro ecology like Hitosa district by considering its yield advantage and profitability.

\section{ACKNOWLEDGEMENT}

The authors would like to acknowledge the Agricultural Growth Programme II of Ethiopian Institute Agricultural Research (EIAR) for the financial support. The active participation of Hitosa district agricultural office expert \& Development agents and Mr.Hashim Gelete researcher at KARC who has a crude knowledge of implementing designed trial \& for his technical assistant from the beginning to end of the activity .Kulumsa Agricultural Center (KARC) for taking the credit for its facilitation during implementation of the activity.

\section{REFERENCES}

Asmamaw Demil , T. A., Yihenew Awoke, Assefa Derebe \& Tilahun Adera (2020). "Bridging the yield gaps of bread wheat at a scale through an innovative method of lime application in the acidic soils of Northwestern Ethiopia." Cogent Food \& Agriculture 6(1803578): 25.

Bekele Gemechu, A. B. A. M. (2018). "Performance evaluation of improved bread wheat (Triticum aestivum L.) varieties and productiontechnologies in Central High Lands of Ethiopia." African Journal of Agricultural Research Vol. 14(7): 8.

CSA (2019/20). The Federal Democratic Repeblic of Ethiopia Centeral Statistical Agency Agricultural Sampe Survey Addis Ababa, CSA. I: 137.

Dereje Dobocha, G. A. a. W. W. (2019). "Grain quality and nitrogen use efficiency of bread wheat (Triticum 
aestivum L.) varieties in response to nitrogen fertilizer in Arsi highlands,southeastern Ethiopia." African Journal of Agricultural Research 14(32): 1544-1552.

HOANR , H. o. o. A. a. N. R. (2019). Major and Cash cropd produced at Hitosa district.

Maitra, S. (2000). "Evaluation On front line Demonstration On Ground nut (Arachis Hypogea.L)i sunderbans." J.Indian Soc.Coastal Agric.Res.,18(2),180-183,2000.

Samuel Gebreselassie, M. G. H. a. M. K. (2017). The Wheat Sector in Ethiopia: Current Status and Key Challenges for Future Value Chain Development. ZEF Working Paper Series, ISSN 1864-6638. J. v. B. Christian Borgemeister, Manfred Denich, Till Stellmacher and Eva Youkhana. Bonn, Center for Development Research, University of Bonn: 42.

Solomon Yokamo, M. L., Endrias Oyka and Tsebaye Tsalla (2018). "Pre Extension Demonstration of wheat Technology Southern Agricultural Research Institute." Agricultural Researc \& Techcinology Open Access Journal 14(3): 5.

Tesfaye Gemechu, F. T. (2018). "Participatory Evaluation and Demonstration of Bread Wheat (Triticumaestivum L) Varieties at Dugda and Lume Districts,Oromia Regional State, Ethiopia." International Journal of Research Studies in Agricultural Sciences (IJRSAS) Volume 4, (Issue 7, 2018): PP 26-30.

Wikipedia, t. f. e. (2020). "Hitosa District." Retrieved 22/09/20, 2020.

Wikipedia, t. f. e. (2020). "Latitude and longitude of Hitosa In Ethiopia." Retrieved 22/09/20, 2020.

Wuletaw Tadesse, Z. B. a. S. A. (2018). "Wheat production and breeding in Sub-Saharan Africa Challenges and opportunities in the face of climate change." International Journal of Climate Change Strategies and Management 11 No. 5, 2018: 20. 